\title{
The John Murray Expedition to the Arabian Sea
}

\section{By Lieut.-Col. R. B. Seymour Stwell, c.I.e., F.R.S.}

$I^{N}$ my previous accounts of the John Murray Expedition (NATURE, 133, 86, 669, Jan. 20 and May 5, 1934), I dealt with the work done up to the time of our arrival in Colombo on February 22 , and in the present paper I give an account of the concluding part of our voyage. While in Colombo, we were joined by Major E. A. Glennie, R.E., of the Survey of India, and his staff, who had been detailed to accompany us through the Maldive Archipelago and carry out observations on the variation of gravity by means of pendulum experiments. Leaving Colombo on March 17, we steamed south-west to a point just north of the Chagos Archipelago, and then turned northward to investigate the depth and hydrographic conditions existing in the channel between the Chagos and Maldive groups of islands. On the completion of this work we visited Addu atoll, and Major Glennie and his apparatus were landed on Putali Island at the north-east corner of the atoll. After leaving Addu atoll we steamed northwards to South Male atoll, landing Major Glennie on the way at Kolumadulu and Mulaku atolls.

At South Male atoll a formal visit was paid to H.H. the Sultan, who very kindly placed a boat at the disposal of the Expedition and thus enabled me to detach a party, consisting of Major Glennie and Lieut.Commander Farquharson, R.N., to carry out pendulum and magnetic observations in a line across Fadiffolu and South Malosmadulu atolls, while the Mabahiss was engaged in hydrographic and biological work in Kardiva Channel and on the western slopes near Horsburgh atoll. During the course of this work, we discovered the existence of a submerged bank, to which we have given the name "King Fuad Bank", lying at a depth of 130 fathoms, and occupying the greater part of the western end of Kardiva channel between Horsburgh atoll and Toddu Island. After ten days we picked up our detached party and proceeded northwards to Minikoi, where Major Glennie was again landed for pendulum observations. On the conclusion of this work we returned to Colombo for coaling and left again, on our return voyage to Aden, on April 19. After passing through Kardiva Channel and running a further line of soundings across King Fuad Bank, we set our course westward, approximately along lat. $7^{\circ} \mathrm{N}$., until we were in about long. $58^{\circ} \mathrm{E}$., when we altered course and, passing between Cape Guardafui and Socotra, again entered the Gulf of Aden. Having repeated the hydrographic observations across the mouth of the Gulf at a series of stations as near as possible to those that we made

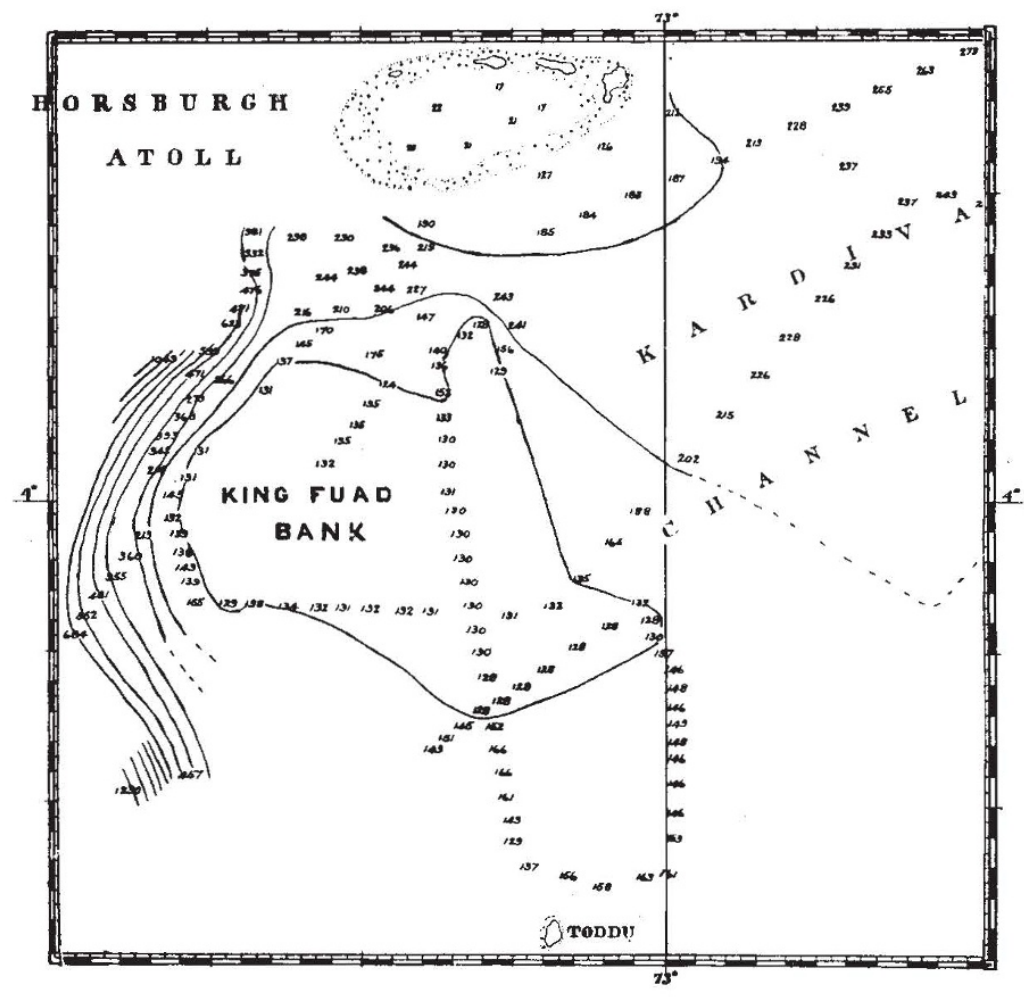

FrG. 1. King Fuad Bank at the western end of Kardiva Channel, Maldive Archipelago. several hauls with the trawl or dredge on both sides of the Gulf, we called in at Aden and on May 13 left for Alexandria, repeating a number of observations that we had made at the head of the Gulf and at the southern end of the Red Sea on our outward journey eight months previously. We reached Alexandria on May 25, and the ship was paid off on the following day.

\section{TOPOGRAPHICAL Results}

On leaving Colombo on our voyage to Addu atoll, we first crossed a deep gully, of about 2,200 fathoms depth, that runs north-west near the southwest corner of Ceylon, and then the depth shoaled again. The greatest depth encountered between 
Ceylon and the channel between the Maldive and Chagos Archipelagoes was about 2,500 fathoms, but as we approached the Archipelagoes the depth shoaled rapidly until we were in about $1,500-1,600$ fathoms, at which depth the bottom remained fairly constant for some distance. In the channel itself the depth of water appears to be in the neighbourhood of 2,000 fathoms with, apparently, a hard bottom, since two attempts to obtain a bottom sample yielded no trace of any deposit.

I have already referred to the discovery of a submerged bank (Fig. 1), situated at the western end of Kardiva channel, and occupying most of the gap between Horsburgh atoll and Toddu Island, to which I have given the name "King Fuad Bank". On the north-east side this bank rises very steeply from some 240 fathoms, the encountered in lat. $7^{\circ} \mathrm{N}$., long. $61^{\circ} 30^{\prime} \mathrm{E}$. Here again there seemed to be indications of a double ridge, for we obtained a sounding of 1,361 fathoms which seemed to correspond with the 958 fathoms sounding obtained between the Seychelles and the Maldives; the soundings then dropped to 1,840 fathoms and in lat. $7^{\circ} \mathrm{N}$., long. $60^{\circ} \mathrm{E}$. a second ridge of only 1,209 fathoms depth was crossed. Shortly after this the ship's course was altered to north-west-by-west. This course was considered to be only a few degrees divergent from the general direction of the ridge, and the soundings for the next fifty minutes fluctuated between 1,230 and 1,340 fathoms with occasional deeper depths. For the next 230 miles the ship was approximately steaming along the 2,000 fathom line, with variations on either side, to lat. $9^{\circ} 20^{\prime} \mathrm{N}$.,

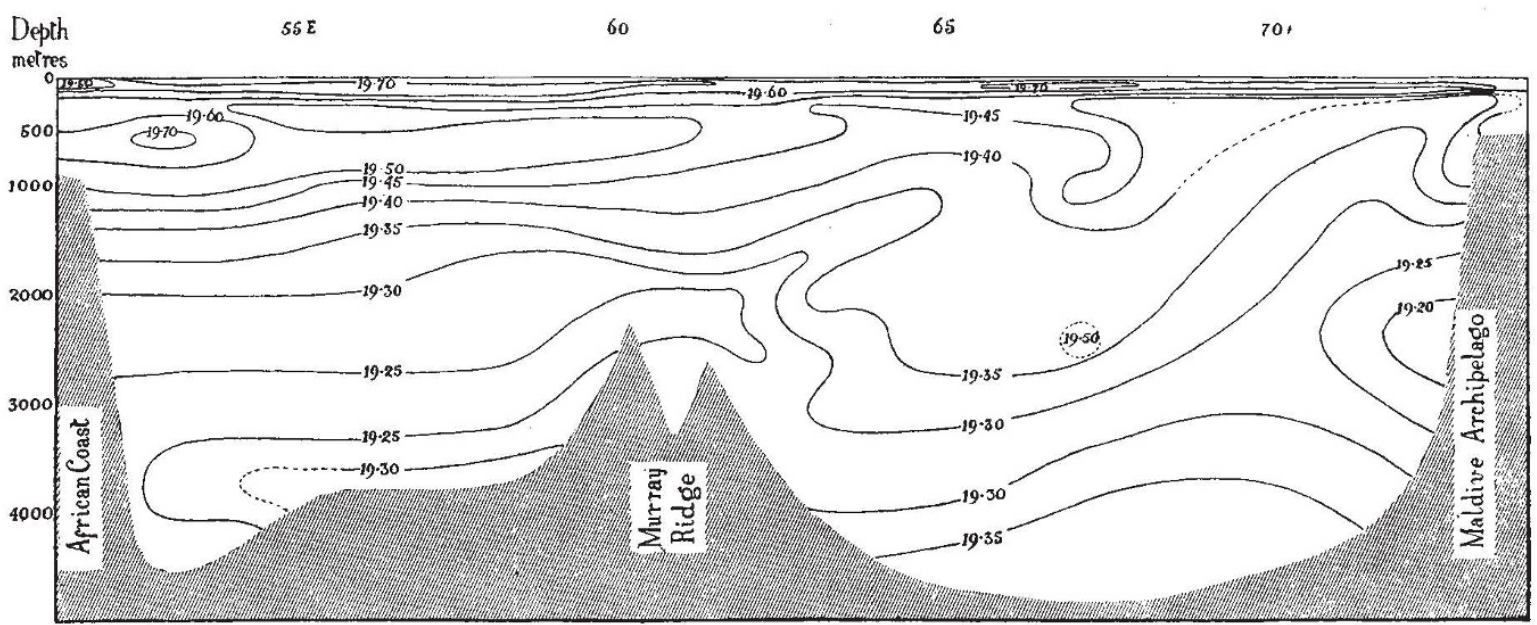

FIG. 2. Halogen content of water between Kardiva Channel and Caps Guardafui.*

general level of the channel, to about 130 fathoms, while on the western side the bank drops steeply down to 1,000 fathoms or more. The surface of the bank is flat and around part of the margin runs a raised rim on which the depth of water is about 125 fathoms. There can be little doubt that this is a submerged atoll, that still shows clearly the flat lagoon floor and, in places, the raised marginal reef.

As we steamed westward in our voyage from Colombo to Aden, the soundings to the westward of the Maldives showed a series of folds, succeeding each other regularly, the depth varying from 2,800 to 2,000 fathoms. These soundings agree with those taken by us between the Seychelles and the Maldives, but in this more northerly section the range is considerably greater. The eastern edge of the great ridge that runs towards the south-east from Socotra, and to which Schmidt has given the name Carlsberg Ridge, was

* It was originally intended to call the ridge between the island of Socotra and the Chagos Archipelago the "Murray Ridge" ; but it has since been discovered that Dr. J. Schmidt, who crossed it in the Dana, had already named it the "Carlsberg Ridge". long. $55^{\circ} 15^{\prime} \mathrm{E}$. , when the soundings dropped steeply to 2,500 fathoms and remained fairly constant until we reached the Guardafui-Socotra channel.

A number of samples of the bottom were obtained. In the north-eastern basin, we obtained a long core, 52 inches, of soft reddish-cream ooze, and from a deep trawl in lat. $6^{\circ} 55^{\prime} 18^{\prime \prime} \mathrm{N}$., long. $67^{\circ} 11^{\prime} 18^{\prime \prime} \mathrm{E}$., depth 4,718-4,793 metres (Station 166) we obtained 125 kilograms of rounded or angular nodules, containing manganese, of varying sizes, but there were no signs of any living organisms, though the net was on the bottom for two hours. Sir John Murray himself many years ago directed attention to the character of the bottom deposit in this region, lying between lat. $5^{\circ}-12^{\circ} \mathrm{N}$. and long. $62^{\circ}-72^{\circ} \mathrm{E}$., which must be classed as a "Red-Clay".

On the Carlsberg Ridge itself, in lat. $7^{\circ} 14^{\prime} \mathrm{N}$., long. $60^{\circ} 38^{\prime} 42^{\prime \prime}$ E., depth 3,182 metres (Station 168), the bottom was rocky; the trawl frame was bent and broken and the net torn, but we obtained a few fragments of foraminiferal limestone. 
While passing through the Straits of Bab el Mandeb and the area to the immediate north in the region of Great Hanish Island, we again obtained clear evidence of the formation of a calcareous rock on the bottom, and in lat. $15^{\circ} 54^{\prime} 36^{\prime \prime} \mathrm{N}$., long. $41^{\circ} 13^{\prime} \mathrm{E}$., we brought up large quantities in the four-foot triangular dredge, mixed with a greenish-brown mud that contained large numbers of pteropod shells.

\section{Hydrographic Results}

During the run across the Arabian Sea a number of hydrographic observations were taken, and a preliminary survey of these observations indicates a complicated circulation of the deeper water masses. The results of the analysis of the halogen content of the water are shown in Fig. 2, and it is interesting to compare this with the figures that I have given in my previous report of the results obtained in our earlier crossing of this region between Bombay and Mombasa (NATURe, 133, 700, Figs. 2 and 3).

The surface water, having a halogen content of $19 \cdot 60$ and above in the western and central area, is moving in an easterly or south-easterly direction sinking somewhat as it goes, until in long. $61^{\circ} \mathrm{E}$. it disappears below the surface and is continued at a depth of some 50 metres. Below this, at $300-400$ metres, there seems to be a westerly movement of water of a somewhat lower halogen content, 19.5 and less, that can be traced as far as long. $55^{\circ} \mathrm{E}$. The main mass of water of halogen content of 19.6 and above, coming out of the Gulf of Aden between the depths of 400 and 800 metres, appears to swing towards the south and passes partly between Cape Guardafui and Socotra but in the main to the east of the island, while farther east between long. $55^{\circ}$ and $62^{\circ} \mathrm{E}$. a tongue of water, having a halogen content of 19.52-19.53, is moving in a south-east or easterly direction. In the south-west basin a mass of water of a halogen content of only $19 \cdot 21$ occupies the greater part of the deep area, and appears to be moving east and north-eastward until, meeting with the Carlsberg Ridge, it is deflected, part passing over the ridge into the north-east basin and part being deflected upwards towards the surface. There can be little doubt that this water of low halogen content is derived ultimately from the Atlantic bottom-drift that probably enters the south-west basin between the Seychelles and Madagascar.

In the north-east basin the surface water appears to be forced downwards, and at a depth of some 700 metres is split into two streams, one passing towards the west, where we have already seen it forming a stratum at a depth of $300-400$ metres, the other sinking downwards until it meets the eastern slope of the Carlsberg Ridge and is then deflected first eastwards, and then upwards towards the surface. The south-east part of the basin in long. $72^{\circ} \mathrm{E}$., between the depths of 2,000 and 3,000 metres, is occupied by

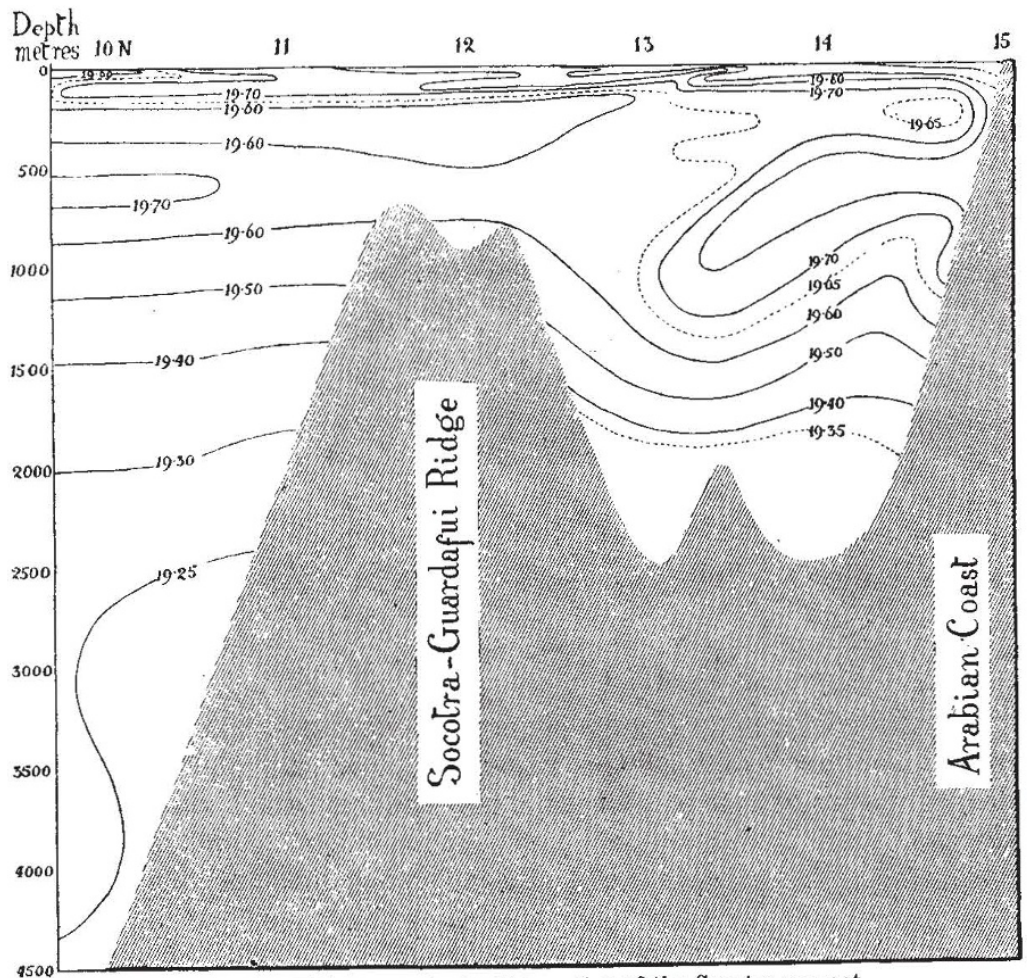

FIG. 3. Halogen content of the water of the Socotra current.

a mass of water of low halogen content, $19 \cdot 25$ or less, that must, again, be derived from the antarctic bottom drift, and probably enters the basin between the Maldives and the Chagos Archipelagoes, where there is a deep channel of some 2,000 fathoms (3,600 metres) depth. Below this depth the bottom of the basin appears to be occupied by water of a somewhat higher halogen content, $19 \cdot 30$ and above, the sample from extreme 4,000 metres depth having a content of $19 \cdot 34$ and at 4,500 metres of $19 \cdot 83$, though this last figure is open to suspicion. In long. $67^{\circ} 11^{\prime} \mathrm{E}$., at a depth of 2,500 metres a mass of water was encountered having a halogen content of 19.50 , while the reading at 2,000 metres was $19 \cdot 36$ and at 3,000 metres $19 \cdot 28$. It is possible that this is the continuation of the outflowing water of high 
halogen content from the Gulf of Oman, that has gradually sunk downwards off the west coast of India and the western slopes of the Laccadive and Maldive Archipelagoes.

The results obtained by repeating our observations in the Socotra current across the entrance to the Gulf of Aden show a considerable degree of similarity with those obtained during our earlier work in September (cf. Nature, 133, 67, Fig. 3 and 87, Fig. 2). In the Straits of Bab el Mandeb, however, conditions were very different and now (April-May) agree closely with the results previously obtained by the Magnaghi and Ormonde at this time of the year.

\section{Biological Results}

- During our cruise through the Maldive Archipelago a number of observations were made, both

\begin{tabular}{|c|c|c|c|c|}
\hline $\begin{array}{l}\text { Sta- } \\
\text { tion } \\
\text { No. }\end{array}$ & Locality & $\begin{array}{c}\text { Depth } \\
\text { (metres) }\end{array}$ & $\begin{array}{l}\text { Nature of } \\
\text { bottom }\end{array}$ & $\begin{array}{c}\text { Amt. of } \mathrm{H}_{2} \mathrm{~S} \\
\text { (mgm. per litre) }\end{array}$ \\
\hline 137 & $\begin{array}{l}\text { Addu atoll, } \\
\text { N.E. corner }\end{array}$ & 46 & $\begin{array}{l}\text { White, chalky } \\
\text { mud }\end{array}$ & $4 \cdot 90$ \\
\hline 139 & $\begin{array}{l}\text { Kolumadulu } \\
\text { atoll, E. side }\end{array}$ & 57 & Coral sand & nil. \\
\hline 141 & $\begin{array}{l}\text { Mulaku } \\
\text { atoll, W. side }\end{array}$ & 44 & $\begin{array}{l}\text { Coarse sand, } \\
\text { shells, coral } \\
\text { and conglom- } \\
\text { erate rock }\end{array}$ & nil. \\
\hline $\begin{array}{l}142 \\
(a)\end{array}$ & $\begin{array}{l}\text { Fadiffolu atoll, } \\
\text { F. side }\end{array}$ & 31 & $\begin{array}{l}\text { Sand and white } \\
\text { mud }\end{array}$ & $3 \cdot 29$ \\
\hline $\begin{array}{l}142 \\
(b)\end{array}$ & ditto. & 37 & $\begin{array}{l}\text { Cream-coloured } \\
\text { mud }\end{array}$ & $2 \cdot 26$ \\
\hline 144 & $\begin{array}{l}\text { Fadiffolu atoll, } \\
\text { W. side }\end{array}$ & 31 & $\begin{array}{l}\text { Coarse coral and } \\
\text { shell sand }\end{array}$ & nil. \\
\hline 147 & $\begin{array}{l}\text { Horsburgh } \\
\text { atoll, N. side }\end{array}$ & 27 & $\begin{array}{l}\text { Soft cream- } \\
\text { coloured mud }\end{array}$ & nil. \\
\hline 160 & $\begin{array}{l}\text { Horsburgh } \\
\text { atoll, N. side }\end{array}$ & 37 & $\begin{array}{l}\text { Cream-coloured } \\
\text { mud }\end{array}$ & $7 \cdot 73$ \\
\hline 161 & $\begin{array}{l}\text { S. Malos- } \\
\text { side }\end{array}$ & 46 & Coarse sand & nil. \\
\hline
\end{tabular}

in the shallow water of the lagoons and in the deeper waters of Kardiva Channel and the western slopes.
One interesting and important discovery that we made was the presence of sulphuretted hydrogen gas in the bottom-deposit of several of the lagoons. The details are given in the accom panying Table.

It will be noted that in every case the presence of the sulphuretted hydrogen is associated with a fine white or cream-coloured mud, and in most cases where the gas was found there were thickly wooded and fertile islands in the near vicinity, so that it seems probable that this gas is caused by the decomposition in the mud of organic material derived from the vegetation of the islands. To what extent the presence of this gas, in such quantities as are indicated above, may influence the fauna or inhibit the growth of coral is a problem that requires investigation.

A slight trace of sulphuretted hydrogen was also detected in a bottom deposit of green mud, obtained at a depth of 95 metres, on the Arabian coast in lat. $13^{\circ} 51^{\prime} 30^{\prime \prime} \mathrm{N}$., long. $47^{\circ} 49^{\prime} 12^{\prime \prime} \mathrm{E}$. (Station 189) in the Gulf of Aden, and this possibly represents a western extension of the conditions found to be present farther to the east off Cape Ras-al-Hadd.

The fauna of Kardiva Channel and the flat level of King Fuad Bank proved to be a rich one, but on the western slopes the catches were disappointing. This may be due partly to the difficulty of trawling successfully on a steep slope, but it would also appear probable that on this western side of the Maldive ridge the fauna is impoverished, and in the depth of the north-eastern basin of the Arabian Sea a trawl of two hours' duration on the Red Clay at a depth of 4,718-4,793 metres yielded no living organisms at all.

\section{The Green Plant and its Messages to Mankind*}

IN this elanging world of constant change, one thing stands fast: the green plant, the greatest wonder of the world, the engineer of life. Some of its messages it sends direct to us by its own special messengers, for example, the vitamins ; others it leaves scientific interpreters to convey. The green plant is the source of the paper upon which the latter messages are written, and when the paper perishes, the plant gathers up the fragments and welds them again into leaf and flower and fibre. It is also the source of coal, of wood, of dyes, spices, fabrics and wine.

The life of the simplest of green plants, Chlamydomonas, tells us of feats of structural engineering beyond human power, and suggests hydraulic systems so perfect that, in spite of its

* Summary of the Thomas Hawksley lecture, "The Green Plant as Agricultural Engineer", given by Sir Frederick Keeble before the Institution of Mechanical Engineers on October 26, 1934. fragility, the green plant can sustain pressures comparable with those of the steam-engine, and that too without shriek or moan. The individual Chlamydomonas is invisible to the naked eye, yet so numerous that at certain times they form a green scum on the edge of the sea and on inland waters. Chlamydomonas is a plant-animal. In its green youth it is active and self-contained; the only materials for its sustenance are solutions of carbon dioxide, simple nitrogen compounds and mineral salts. From these it builds up sugar and starch by photosynthesis, and amino-compounds and proteins with the help of oxygen derived from nitrates in the sea-water. A powerful swimmer for its size, it propels itself by means of long, slender protoplasmic threads towards the light. But these 'salad' days come to an end. The solitary swimmers unite by fusion, protoplasm with 